\title{
Notification Features on Android-Based Job Vacancy Information System
}

\author{
Ketut Arif Suidiantara \\ Department of Information \\ Technology \\ Faculty of Engineering \\ Udayana University \\ Badung, Bali, Indonesia
}

\author{
I Nyoman Piarsa \\ Department of Information \\ Technology \\ Faculty of Engineering \\ Udayana University \\ Badung, Bali, Indonesia
}

\author{
Dwi Putra Githa \\ Department of Information \\ Technology \\ Faculty of Engineering \\ Udayana University \\ Badung, Bali, Indonesia
}

\begin{abstract}
Job vacancy is an information created by a company that contains certain requirements. There are many job vacancies that are published by the company. However, the range in delivering and spreading their information is still limited. Therefore, it is very hard to discover this information. Submission of job applications is generally still in the conventional way, which is by printing the application, then coming to the company to submit it. This job application process becomes an obstacle for job applicants because they have to pay more for transportation and printing cost. Another obstacle is the difficulty in getting information about the status of their applications that have been submitted. An Android-based job application is developed in the Android platform to overcome the problems related to the job vacancy. The implementation process utilizes Web Service, Firebase System, PhpMyAdmin, and Android smartphones. This Android-based job information system with the notification features is a solution to improve the quality of service and spread job vacancy information from a company. Furthermore, it also can help the applicants in sending applications at the intended company.
\end{abstract}

Keywords: information system; notification; job vacancy; android; firebase.

\section{INTRODUCTION}

Job vacancy is an information created by a company that contains certain requirements. There are many job vacancies that are published by the company. However, the range in delivering and spreading their information is still limited. Therefore, job applicants have a hard time to discover this information. Generally, the submission of job applications is still in the conventional way, which is by printing the application, then coming to the company to submit it. This job application process becomes an obstacle for job applicants because they have to pay more for transportation and printing cost. Another obstacle is the difficulty in getting information about the status of their applications that have been submitted. Information technology is currently utilizing the internet in the delivery of information because it is real-time and it does not cost a lot in its use. The internet can be accessed through many devices such as computers, laptops, smartphones, and even televisions. Delivering information by using the internet has more advantages because it has a very wide range. The information published on the internet can be seen by people all over the world. Notification feature is an example of the use of the internet in information technology. In addition, it is used to convey information in real time. The notification feature is used in this study to overcome problems related to the job vacancy information delivery and job application status that has been sent to the system.

A solution offered for this problem is in the form of an Android-based Job Vacancy Information System application which aimed at job applicants. The notification features in the application are intended to overcome the problems experienced by job applicants. As the result, they do not have to spend money for transportation and printing cost because they can submit and send their applications online to the company by using the system. In addition, the system also utilizes this feature as a place for delivering the latest information about the status of applications that have been submitted by the job applicant in real-time.

\section{LITERATURE REVIEW}

A study by Siti Maisaroh discusses an Android-based and web services information system of job vacancy in Tangerang. The developed Android-based applications can link the relationship between the job providers and job applicants efficiently. It is because there is an information facility of the company in the Android application. The web service is used to make it easier for administrators to update and manage job information. All data that is displayed on the Android application can be managed through a web service [1]. A study by Natas Dwi Renggo discusses an application for CV. Cakra Surya Nusantara. The application applies firebase notification as a means of delivering information about honey stock to customers. It aims to control the customer's honey stock and make it easier for owners to run their business [2].

\section{RESEARCH METHODS}

There are four steps in conducting this research, namely requirements analysis, system workflow design, system development, and system testing. If the step of system testing has been going well, then the step of system developed has been successfully completed. The display of the research method is shown in Figure 1. 


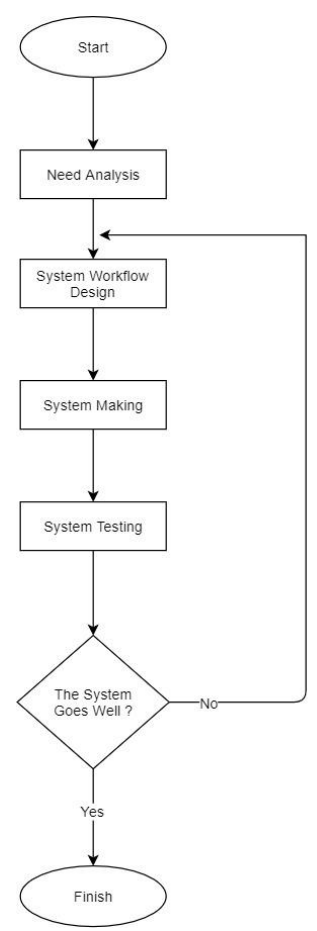

Figure. 1 Reaserch Method

The first step is analyzing the needs of both the applicant and the company. This step is carried out to determine the design of the developed application and the needs of both parties. The second step is designing the system workflow. The design needs to be done, therefore the system is able to function according to specified procedures. The third step is creating a system, both an Android system for applicants, and a web service intended for companies as a place to manage data. The fourth step is system testing. The developed application is then tested to find out whether there are errors in the system. If yes, then a redesign of the system workflow is performed in order to correct errors in it.

\subsection{System Overview}

The Android-Based Job Vacancy Application with Notification Feature has a general overview which contains applicants, companies, and admins. It can be seen in Figure 2.

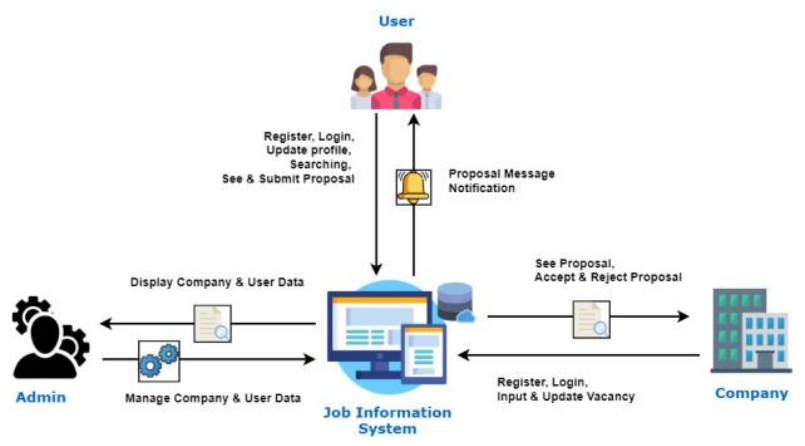

Figure. 2 System Overview

Companies can register, $\log$ in, input \& update vacancies (containing requirements, expertise). Admin functions as a data receiver and data processor from users and companies. The job vacancy information system functions as a forum for delivering user information and applications sent to companies. Job seekers can register, log in, input \& update profiles, search, and submit applications in the job information system. Job applicants get notifications, such as their application status that is processed, accepted or rejected by the company.

\section{CONCEPTS AND THEORIES}

This section contains supporting theories in conducting this research, such as Android, web server, firebase, cloud computing, and MySQL.

\subsection{Android}

Android is a linux-based operating system used for mobile devices. It is the first operating system that can be downloaded for free, designed by Google [3]. The android information system applications are divided into three developments, namely the development of PHP and Java programming languages (hybrid applications), development of PHP programming languages (web applications), and development of Java programming languages (Java applications) [4].

\subsection{Web Server}

A web server is a hardware (server) and software that provides an access service for users through HTTP and other types of communication protocols such as HTTPS and FTP over documents stored at a URL for users [5].

\subsection{Firebase}

Firebase is a technology that allows developers to create web applications without server-side programming, therefore its development is easier and faster. It is also allows developers to use the Firebase Cloud Messaging (FCM) feature. The main capability of FCM is that it can send messages in the form of notifications and data. The Firebase provides a capacity of 10 gigabytes for data transfer and an additional 1 gigabyte for storage [6].

\subsection{Cloud Computing}

Cloud computing technology is a technology where most of the computing and processes are located on the internet. As the result, the users can access the desired service at all locations as long as it has internet access. The cloud computing is also a technology that allows IT resources to be used in various types of platforms, different systems, and program codes. Therefore, it can be integrated with various types of services and uses. In addition, it is a service model that utilizes a configured computing resource (for example servers, networks, systems, storage, and services) and can be run through the internet. The advantage of cloud technology is that users can store data in a structured and centralized manner in one server on the services provided by service providers [7].

\subsection{MySQL}

MySQL is a management system of SQL Database that is very popular because it is open source. The MySQL Database System has several supporting features such as the SQL Database management system (DBMS), multiuser, and multithreaded [8].

\section{RESULTS AND DISCUSSION}

The results and discussion of the Job Vacancy Information System application include direct system testing, Black Box Testing, and questionnaire testing. The results of these three tests will be discussed as follows.

\subsection{System Testing}

The job applicants can view and submit their job applications in selected vacancies. In addition, they can receive and view notification messages from the company when their submitted 
job applications are in the process of checking. This test is carried out directly by using the Job Vacancy Information System application. Job vacancies and application submissions are show in Figure 3.

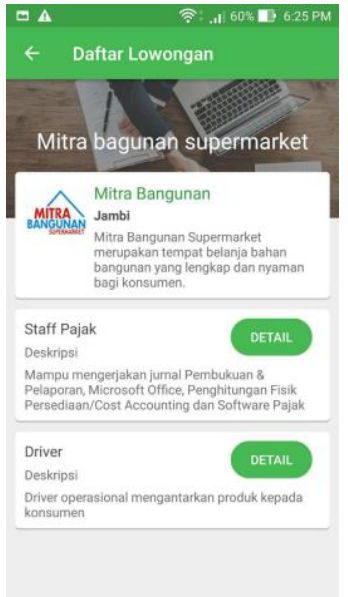

(a)

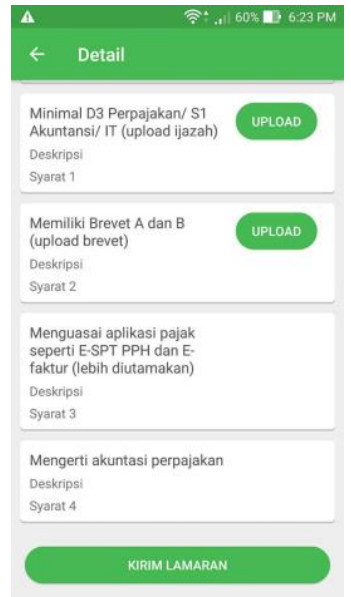

(b)
Figure. 3 Application Submit Feature

Figure 3 shows a step in sending a job application to the company through the application of a job applicant. Figure 3 (a) is a detailed view of the job vacancies in which it contains the required skills in the vacancy. Figure 3(b) is a display of the expertise details, in which the applicant must complete the requirement file (upload) required by the company before sending their job applications. Display notifications and notification messages related to the job applications that have been sent are shown in Figure 3.

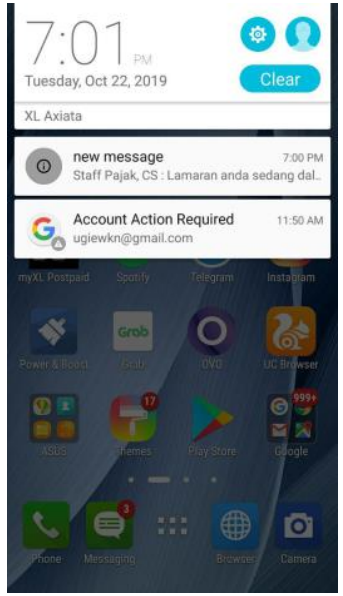

(a)

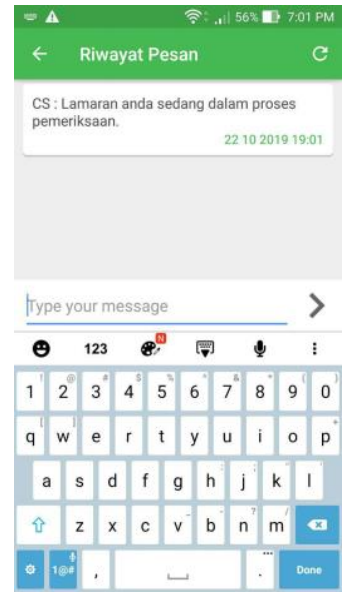

(b)
Figure. 4 Notification Feature

Figure 4(a) is a notification display where the job applications that have been sent previously are processed by the company. Figure 4(b) is a display of the message history or notification message details that the company sends to the job applicant. In addition, the job applicant can send messages directly through Job Vacancy Information System application.

\subsection{Black Box Testing}

Black box testing is a technique of testing functional systems based on specific test cases. The test is carried out to evaluate the system on interface display (external) without knowing what is happening in the coding section. The purpose of black box testing is to find out failures or errors in the systems that cover operational, system scenarios, and capabilities. The black box testing table can be seen in Table 1 .

Table 1. Black Box Testing

\begin{tabular}{|c|c|c|c|}
\hline Test Name & $\begin{array}{l}\text { Expected } \\
\text { results }\end{array}$ & Test result & Result \\
\hline $\begin{array}{l}\text { Create an } \\
\text { Account }\end{array}$ & $\begin{array}{l}\text { Entering } \\
\text { registration } \\
\text { data and } \\
\text { make a } \\
\text { registration }\end{array}$ & $\begin{array}{l}\text { Job applicants } \\
\text { successfully } \\
\text { entered } \\
\text { registration } \\
\text { data and make } \\
\text { a registration }\end{array}$ & $\begin{array}{c}{[\mathrm{x}]} \\
\text { Accepted } \\
\\
{[\mathrm{]}} \\
\text { Rejected }\end{array}$ \\
\hline Verification & $\begin{array}{l}\text { Receiving } \\
\text { verification } \\
\text { email }\end{array}$ & $\begin{array}{l}\text { Job applicants } \\
\text { successfully } \\
\text { received a } \\
\text { verification } \\
\text { message in } \\
\text { the email }\end{array}$ & $\begin{array}{c}{[\mathrm{x}]} \\
\text { Accepted } \\
{[\mathrm{]}} \\
\text { Rejected }\end{array}$ \\
\hline $\begin{array}{l}\text { Login into } \\
\text { the } \\
\text { application }\end{array}$ & $\begin{array}{l}\text { Registration } \\
\text { data has } \\
\text { been verified } \\
\text { and can be } \\
\text { logged into } \\
\text { the } \\
\text { application }\end{array}$ & $\begin{array}{l}\text { Registration } \\
\text { data are valid } \\
\text { and } \\
\text { successfully } \\
\text { used to enter } \\
\text { the } \\
\text { application }\end{array}$ & $\begin{array}{c}{[\mathrm{x}]} \\
\text { Accepted } \\
{[\mathrm{]}} \\
\text { Rejected }\end{array}$ \\
\hline $\begin{array}{l}\text { Find a job } \\
\text { vacancy }\end{array}$ & $\begin{array}{l}\text { Displaying } \\
\text { the name of } \\
\text { the job } \\
\text { vacancy }\end{array}$ & $\begin{array}{l}\text { The name of } \\
\text { the job } \\
\text { vacancy was } \\
\text { successfully } \\
\text { displayed }\end{array}$ & $\begin{array}{c}{[\mathrm{x}]} \\
\text { Accepted } \\
{[\mathrm{]}} \\
\text { Rejected }\end{array}$ \\
\hline $\begin{array}{l}\text { See the job } \\
\text { vacancy } \\
\text { information }\end{array}$ & $\begin{array}{l}\text { Displaying } \\
\text { company } \\
\text { information } \\
\text { and } \\
\text { available } \\
\text { expertise }\end{array}$ & $\begin{array}{l}\text { Successfully } \\
\text { received } \\
\text { company } \\
\text { information } \\
\text { and available } \\
\text { expertise }\end{array}$ & $\begin{array}{c}{[\mathrm{x}]} \\
\text { Accepted } \\
{[\mathrm{]}} \\
\text { Rejected }\end{array}$ \\
\hline $\begin{array}{l}\text { See } \\
\text { expertise } \\
\text { information }\end{array}$ & $\begin{array}{l}\text { Displaying } \\
\text { the } \\
\text { requirements } \\
\text { needed in } \\
\text { the chosen } \\
\text { expertise }\end{array}$ & $\begin{array}{l}\text { The } \\
\text { requirements } \\
\text { of the chosen } \\
\text { expertise } \\
\text { were } \\
\text { successfully } \\
\text { displayed }\end{array}$ & $\begin{array}{c}{[\mathrm{x}]} \\
\text { Accepted } \\
{[\mathrm{]}} \\
\text { Rejected }\end{array}$ \\
\hline $\begin{array}{l}\text { Upload a } \\
\text { requirement } \\
\text { file }\end{array}$ & $\begin{array}{l}\text { Selecting } \\
\text { files to } \\
\text { upload } \\
\text { according to } \\
\text { the } \\
\text { requirement } \\
\text { of the } \\
\text { chosen } \\
\text { expertise }\end{array}$ & $\begin{array}{l}\text { Successfully } \\
\text { selected, } \\
\text { entered and } \\
\text { displayed the } \\
\text { name of the } \\
\text { uploaded file }\end{array}$ & $\begin{array}{c}{[\mathrm{x}]} \\
\text { Accepted } \\
{[\mathrm{]}} \\
\text { Rejected }\end{array}$ \\
\hline $\begin{array}{l}\text { Submit a job } \\
\text { application }\end{array}$ & $\begin{array}{l}\text { Sending a } \\
\text { job } \\
\text { application } \\
\text { can be } \\
\text { performed }\end{array}$ & $\begin{array}{l}\text { The job } \\
\text { application } \\
\text { was } \\
\text { successfully } \\
\text { sent to the } \\
\text { selected } \\
\text { expertise }\end{array}$ & $\begin{array}{c}{[\mathrm{x}]} \\
\text { Accepted } \\
{[\mathrm{]}} \\
\text { Rejected }\end{array}$ \\
\hline $\begin{array}{l}\text { Job } \\
\text { Application } \\
\text { History }\end{array}$ & $\begin{array}{l}\text { Displaying } \\
\text { the job } \\
\text { application } \\
\text { history data } \\
\text { that have }\end{array}$ & $\begin{array}{l}\text { Successfully } \\
\text { showed the } \\
\text { submitted job } \\
\text { application } \\
\text { history data }\end{array}$ & $\begin{array}{c}{[\mathrm{x}]} \\
\text { Accepted } \\
{[\mathrm{]}} \\
\text { Rejected }\end{array}$ \\
\hline
\end{tabular}




\begin{tabular}{|c|c|c|c|}
\hline & $\begin{array}{l}\text { been } \\
\text { submitted }\end{array}$ & & \\
\hline $\begin{array}{l}\text { Cancel Job } \\
\text { Application }\end{array}$ & $\begin{array}{l}\text { Sending job } \\
\text { application } \\
\text { cancellation } \\
\text { messages } \\
\text { and } \\
\text { canceling } \\
\text { job } \\
\text { applications } \\
\text { that have } \\
\text { been made }\end{array}$ & $\begin{array}{l}\text { Successfully } \\
\text { canceled the } \\
\text { job } \\
\text { application } \\
\text { and delivered } \\
\text { a cancellation } \\
\text { message }\end{array}$ & $\begin{array}{c}{[\mathrm{x}]} \\
\text { Accepted } \\
{[\text { [ ] }} \\
\text { Rejected }\end{array}$ \\
\hline $\begin{array}{l}\text { Message } \\
\text { history }\end{array}$ & $\begin{array}{l}\text { Displaying } \\
\text { message } \\
\text { history and } \\
\text { the message } \\
\text { sent }\end{array}$ & $\begin{array}{l}\text { Successfully } \\
\text { showed } \\
\text { message } \\
\text { history and } \\
\text { the message } \\
\text { sent }\end{array}$ & $\begin{array}{c}{[\mathrm{x}]} \\
\text { Accepted } \\
{\left[\begin{array}{l}{[]} \\
\text { Rejected }\end{array}\right.}\end{array}$ \\
\hline $\begin{array}{l}\text { Receive } \\
\text { Notifications }\end{array}$ & $\begin{array}{l}\text { Receiving } \\
\text { notification } \\
\text { messages on } \\
\text { an Android } \\
\text { device }\end{array}$ & $\begin{array}{l}\text { Successfully } \\
\text { received } \\
\text { notification in } \\
\text { the form of a } \\
\text { pop up } \\
\text { notification } \\
\text { on an Android } \\
\text { device }\end{array}$ & $\begin{array}{c}{[\mathrm{x}]} \\
\text { Accepted } \\
{\left[\begin{array}{c}{[]} \\
\text { Rejected }\end{array}\right.}\end{array}$ \\
\hline $\begin{array}{l}\text { Receive } \\
\text { Reminder }\end{array}$ & $\begin{array}{l}\text { Receiving } \\
\text { notifications } \\
\text { and } \\
\text { reminder } \\
\text { messages } \\
\text { about the } \\
\text { information } \\
\text { on job } \\
\text { interview }\end{array}$ & $\begin{array}{l}\text { Successfully } \\
\text { received a } \\
\text { notification } \\
\text { and reminder } \\
\text { message } \\
\text { when the } \\
\text { interview will } \\
\text { be held }\end{array}$ & $\begin{array}{c}{[\mathrm{x}]} \\
\text { Accepted } \\
{[\text { [ ] }} \\
\text { Rejected }\end{array}$ \\
\hline $\begin{array}{l}\text { Update } \\
\text { Profile }\end{array}$ & $\begin{array}{l}\text { Displaying } \\
\text { job applicant } \\
\text { data and can } \\
\text { change the } \\
\text { data }\end{array}$ & $\begin{array}{l}\text { Successfully } \\
\text { showed job } \\
\text { applicant data } \\
\text { and the data } \\
\text { successfully } \\
\text { changed }\end{array}$ & $\begin{array}{c}{[\mathrm{x}]} \\
\text { Accepted } \\
{\left[\begin{array}{c}{[]} \\
\text { Rejected }\end{array}\right.}\end{array}$ \\
\hline $\begin{array}{l}\text { Exit } \\
\text { Application }\end{array}$ & $\begin{array}{l}\text { Returning to } \\
\text { login display }\end{array}$ & $\begin{array}{l}\text { Successfully } \\
\text { returned to } \\
\text { login display }\end{array}$ & $\begin{array}{c}\mathrm{x}] \\
\text { Accepted } \\
{[\mathrm{]}} \\
\text { Rejected }\end{array}$ \\
\hline
\end{tabular}

The result of black box test in Table 1 shows that the job applicants can create an account on the Application. After the account is created, they will receive a verification email containing a link for the activation of the registered account. Then, they can login to the application by entering the correct email and password. The job applicants also can find for the desired job vacancies in the search column. Furthermore, they can see information about the chosen vacancy. The required information that is needed in the chosen expertise can be shown. Then, they can upload files on the requirement that needed file uploads. After all the requirements have been fulfilled, then the job applicant can send their job applications directly through the Application. A list of their submitted job applications can be seen in the application history. In addition, the job applicants can cancel their submitted job application and include the reasons. Furthermore, they can see and send messages to the company. They will receive a notification if their submitted job application has been processed by the company. A reminder notification for interviewing will also be received by them. Profile data that was filled in during registration can be changed. The job applicant can exit the application if they want.

\subsection{Questionnaire Testing}

Besides black box testing, the questionnaire is also used in testing Job Vacancy Application. The questionnaire was distributed to 35 respondents, such as 30 respondents for job applicants and 5 respondents for companies. A table of 30 job applicant respondents can be seen in Table 2 .

Table 2. Test Results of Job Applicant Respondent

\begin{tabular}{|c|c|c|c|c|}
\hline Question & SA & $\mathbf{A}$ & DA & SDA \\
\hline $\begin{array}{l}\text { Is the display provided by this } \\
\text { application easy to } \\
\text { understand? }\end{array}$ & $57 \%$ & $43 \%$ & & \\
\hline $\begin{array}{l}\text { Are the features provided in } \\
\text { the Application easy to use? }\end{array}$ & $53 \%$ & $47 \%$ & & \\
\hline $\begin{array}{l}\text { Does the vacancy information } \\
\text { provide on this Application } \\
\text { suit your needs? }\end{array}$ & $20 \%$ & $80 \%$ & & \\
\hline $\begin{array}{l}\text { Is this application easy to } \\
\text { learn? }\end{array}$ & $47 \%$ & $40 \%$ & $13 \%$ & \\
\hline $\begin{array}{l}\text { Is this application easy to } \\
\text { operate? }\end{array}$ & $47 \%$ & $43 \%$ & $10 \%$ & \\
\hline $\begin{array}{l}\text { Have you easily avoided } \\
\text { mistakes when using the } \\
\text { Application? }\end{array}$ & $33 \%$ & $57 \%$ & $10 \%$ & \\
\hline $\begin{array}{l}\text { Is the menu display in the } \\
\text { Application easy to } \\
\text { recognize? }\end{array}$ & $47 \%$ & $50 \%$ & $3 \%$ & \\
\hline $\begin{array}{l}\text { Are you helped by the } \\
\text { Notification feature as a } \\
\text { service media? }\end{array}$ & $47 \%$ & $53 \%$ & & \\
\hline $\begin{array}{l}\text { Are you helped by the } \\
\text { Reminder feature as a service } \\
\text { media? }\end{array}$ & $50 \%$ & $50 \%$ & & \\
\hline $\begin{array}{l}\text { Are you helped by the } \\
\text { Message feature and Message } \\
\text { History as a service media? }\end{array}$ & $53 \%$ & $47 \%$ & & \\
\hline $\begin{array}{l}\text { Do you feel comfortable with } \\
\text { the Verify email as a security } \\
\text { feature? }\end{array}$ & $40 \%$ & $60 \%$ & & \\
\hline $\begin{array}{l}\text { Are you helped by the Send } \\
\text { Job Application feature as a } \\
\text { service media? }\end{array}$ & $60 \%$ & $40 \%$ & & \\
\hline $\begin{array}{l}\text { Are you satisfied with the } \\
\text { features provided in this } \\
\text { application? }\end{array}$ & $47 \%$ & $53 \%$ & & \\
\hline $\begin{array}{l}\text { Are you interested in finding a } \\
\text { job with this application? }\end{array}$ & $47 \%$ & $53 \%$ & & \\
\hline $\begin{array}{l}\text { Are you interested in inviting } \\
\text { your family or friends to use } \\
\text { this application? }\end{array}$ & $43 \%$ & $57 \%$ & & \\
\hline Total & $46 \%$ & $52 \%$ & $2 \%$ & \\
\hline
\end{tabular}

The total percentage of the questionnaire result that is distributed to 30 job applicant respondents is $46 \%$ of answers strongly agree, $52 \%$ of answers agree, and $2 \%$ of answers disagree. The percentage diagram of the total results from the questionnaire calculation is shown in Figure 5. 


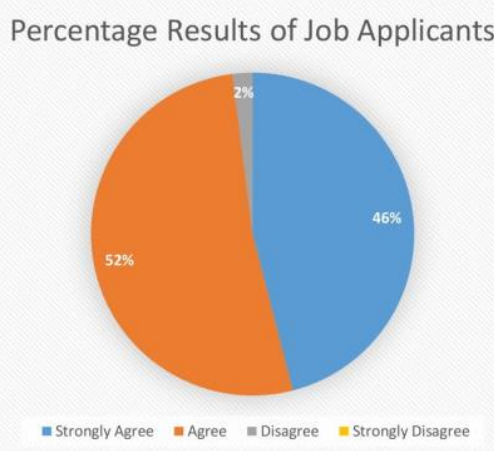

Figure. 5 Percentage Results of Job Applicants

Figure 5 displays the result percentage of the job vacancy application test by using questionnaire media towards job applicant respondents. The questionnaire was also distributed to 5 companies with a total of 15 questions. It was performed to see the results from the company's point of view regarding the developed application. Table of test results of the job vacancy application for company respondents can be seen in table 3 .

Table 3. Test Results of Company Respondent

\begin{tabular}{|c|c|c|c|c|}
\hline $\begin{array}{l}\text { Question } \\
\end{array}$ & SA & $\mathbf{A}$ & DA & SDA \\
\hline $\begin{array}{l}\text { Is the display provided by } \\
\text { this application easy to } \\
\text { understand? }\end{array}$ & $80 \%$ & $20 \%$ & & \\
\hline $\begin{array}{l}\text { Are the features provided in } \\
\text { the Application easy to use? }\end{array}$ & $80 \%$ & $20 \%$ & & \\
\hline $\begin{array}{l}\text { Does the job vacancy } \\
\text { information provide on this } \\
\text { Application suit your } \\
\text { needs? }\end{array}$ & $60 \%$ & $40 \%$ & & \\
\hline $\begin{array}{l}\text { Is this application easy to } \\
\text { learn? }\end{array}$ & $40 \%$ & $60 \%$ & & \\
\hline $\begin{array}{l}\text { Is this application easy to } \\
\text { operate? }\end{array}$ & $40 \%$ & $60 \%$ & & \\
\hline $\begin{array}{l}\text { Have you easily avoided } \\
\text { mistakes when using the } \\
\text { Application? }\end{array}$ & $60 \%$ & $40 \%$ & & \\
\hline $\begin{array}{l}\text { Is the menu display in the } \\
\text { Application easy to } \\
\text { recognize? }\end{array}$ & $80 \%$ & $20 \%$ & & \\
\hline $\begin{array}{l}\text { Are you helped by the } \\
\text { Notification feature as a } \\
\text { service media? }\end{array}$ & $40 \%$ & $60 \%$ & & \\
\hline $\begin{array}{l}\text { Are you helped by the } \\
\text { Reminder feature as a } \\
\text { service media? }\end{array}$ & $60 \%$ & $40 \%$ & & \\
\hline $\begin{array}{l}\text { Are you helped by Message } \\
\text { feature and Message } \\
\text { History as a service media? }\end{array}$ & $40 \%$ & $60 \%$ & & \\
\hline $\begin{array}{l}\text { Do you feel comfortable } \\
\text { with the Verify email as a } \\
\text { security feature? }\end{array}$ & $60 \%$ & $40 \%$ & & \\
\hline $\begin{array}{l}\text { Are you helped by the Send } \\
\text { Job Application feature as a } \\
\text { service media? }\end{array}$ & $40 \%$ & $60 \%$ & & \\
\hline $\begin{array}{l}\text { Are you satisfied with the } \\
\text { features provided in this } \\
\text { application? }\end{array}$ & $20 \%$ & $80 \%$ & & \\
\hline $\begin{array}{l}\text { Are you interested in } \\
\text { finding a job with this } \\
\text { application? }\end{array}$ & $20 \%$ & $80 \%$ & & \\
\hline
\end{tabular}

\begin{tabular}{|l|l|l|l|l|}
\hline $\begin{array}{l}\text { Are you interested in } \\
\text { inviting your family or } \\
\text { friends to use this } \\
\text { application? }\end{array}$ & $20 \%$ & $80 \%$ & & \\
\hline Total & $\mathbf{4 9 \%}$ & $\mathbf{5 1 \%}$ & & \\
\hline
\end{tabular}

The total percentage of the questionnaire result that is distributed to 5 company respondents is $49 \%$ answers strongly agree and 51\% answers agree. The percentage diagram of the total results from the questionnaire calculation is shown in Figure 6.

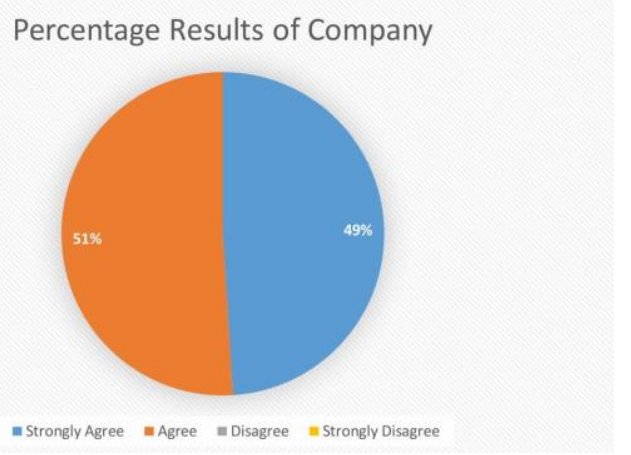

Figure. 6 Percentage Results of Company

Figure 6 shows the result percentage of the job vacancy application test by using questionnaire media towards the company. It shows $49 \%$ strongly agree and $51 \%$ agree.

\section{CONCLUSION}

Job Vacancy Information System is designed and applied in the form of an Android mobile application. The application is designed as a medium for delivering job vacancy information to job applicants. It is developed specifically for mobile devices with the Android platform that can be used by the job applicants. The process of storing and processing data is carried out by an application by using MySQL to support a centralized database service. In addition, it utilizes the Firebase Cloud Messaging (FCM) feature as a delivery medium for notifications on Android mobile devices. Notifications are delivered by the company on the web service to the Android mobile of the job applicants. It is sent when a new job vacancy has been published, job applications are in the process of examination or interview, and accepted or rejected.

\section{REFERENCES}

[1] S. Maisaroh, O. Fajarianto, and M. Nasir, "Sistem Informasi Lowongan Kerja Kota Tangerang Berbasis Android dan Web Service," vol. 9, no. 1, pp. 112-117, 2019.

N. D. Renggo, "Penerapan Firebase Notification Persediaan Stok Madu Pelanggan Pada Aplikasi Cv. Cakra Surya Nusantara," vol. 3, no. 2, 2019.

[3] I. K. K. Sanjaya, P. W. Buana, and I. M. Sukarsa, "Designing Mobile Transactional Based Restaurant Management," vol. 11, no. 6, pp. 130-136, 2019.

[4] M. Harmadya, G. Made AryaSasmita, and N. Ayu Wirdiani, "Rancang Bangun Aplikasi Tryout Ujian Nasional Sekolah Menengah Pertama (Smp) Berbasis Android," Lontar Komput., vol. 6, no. 2, pp. 108-119, 2015.

[5] A. Prayitno and Y. Safitri, "Pemanfaatan Sistem Informasi Perpustakaan Digital Berbasis Website 
International Journal of Computer Applications Technology and Research

Volume 8-Issue 11, 429-434, 2019, ISSN:-2319-8656

Untuk Para Penulis," vol. 1, no. 1, pp. 1-10, Sep. 2015.

[6] A. Rahmi, N. Piarsa, and P. Wira Buana, "FinDoctorInteractive Android Clinic Geographical Information System Using Firebase and Google Maps API," Int. J. New Technol. Res., no. 3, pp. 8-12, 2017.

[7] P. S. Saputra, I. M. Sukarsa, and I. P. A. Bayupati,
"Sistem Informasi Monitoring Perkembangan Anak di Sekolah Taman Kanak - kanak Berbasis Cloud," Lontar Komput. J. Ilm. Teknol. Inf., vol. 8, 2017.

[8] F. Ayu and N. Permatasari, "Perancangan Sistem Informasi Pengolahan Data Praktek Kerja Lapangan (PKL) Pada Devisi Humas Pt. Pegadaian,” Intra-Tech, vol. 2, no. 2, pp. 12-26, 2018. 